DOI: $10.19195 / 8060-0716.26 .9$

\title{
Diminutief in de dagelijkse sociale interacties in Vlaanderen*
}

\begin{abstract}
This paper, using a corpus of 10 contemporary Flemish films (app. 83,000 words), aims to look at the qualitative and quantitative use of diminutives in everyday communication in Flanders. The first part of the study focuses on determining which functions they fulfill in a given context. The question is whether this set functions would only be specific to Flanders or whether it could be seen as a cultural script throughout the whole Dutch language area. The second part of the study is a comparative analysis of the qualitative and quantitative use of diminutives in Loft and Zot van A and their Dutch versions: Loft and Alles is liefde.
\end{abstract}

\section{Inleiding ${ }^{1}$}

"[O]mdat men daardoor achter de taal de levende mens kan zien, en, anderzijds, uit de levende, denkende en sprekende mens de taal kan naderen" schrijft Staverman (1953: 407) in zijn bijdrage "Diminutivis Neerlandica". Op die manier pleit hij ervoor om meer nadruk te leggen op de analyse van "de betekenis en de gevoelssfeer" van de verkleinwoorden. Daarachter liggen namelijk de attitudes en intenties van de spreker. Aangezien de diminutieven zowel een positieve als negatieve lading kunnen hebben, is het mogelijk om dezelfde informatie, afhankelijk van de bedoelingen van de spreker en/of de context van de situatie, op verschillende manieren over te brengen: de manier die aansluit op de communicatieve noden die de taalgebruiker op dat moment heeft. Door diminutieven te gebruiken kan de spreker onder andere de negatieve lading van zijn uitspraak verzachten, zijn verzoek minimaliseren, genegenheid of juist ironie en afstand uitdrukken. Juist die veelzijdigheid van de

* Deze bijdrage is een herziene en uitgebreide uitwerking van een onderdeel van mijn doctorale onderzoek naar het linguïstische beeld van de dagelijkse realiteit in Vlaanderen (Wiercińska 2016).

${ }^{1}$ Met dank aan de beide anonieme reviewers voor hun inhoudelijke suggesties en redactionele adviezen.

Neerlandica Wratislaviensia 26, 2016

(C) for this edition by CNS 
mogelijkheden tot informatieoverdracht maakt het verkleinwoord een intrigerend fenomeen. Schneider (2013: 137) schrijft in de inleiding van zijn artikel "The Truth about Diminutives, and How We Can Find It: Some Theoretical and Methodological Considerations" zelfs dat "de waarheid over de diminutieven niet gemakkelijk te vinden is gezien de specificiteit van dit fenomeen". Temeer omdat de manier waarop ze worden gebruikt, taalspecifiek is.

Deze bijdrage richt zich op het gebruik van diminutieven in de dagelijkse sociale interacties in Vlaanderen. Door middel van een kwalitatieve en kwantitatieve analyse wordt getracht om een antwoord te geven op twee vragen: ten eerste welke sociale functies vervuld worden door diminutieven in informele gesprekken en ten tweede, of dat 'setje' functies gemeenschappelijk is voor Nederland en Vlaanderen. Bij het eerste gedeelte van het onderzoek (gedeeltelijk beschreven in een eerdere studie: Wiercińska 2016) wordt gebruik gemaakt van een corpus ${ }^{2}$ dat de dialogen uit tien Vlaamse films bevat (ca. 18 uur materiaal, ruim 83.000 woorden). Daar zijn in totaal 497 diminutieven gevonden die relevant zijn voor de interpersoonlijke relaties en dus een inzicht kunnen geven in de interactiestandaarden van de Vlaamse samenleving. Twee van de corpusfilms, namelijk Loft en Zot van $A$, hebben nog een Nederlandse versie (respectievelijk Loft en Alles is liefde) die in het tweede gedeelte van het onderzoek worden gebruikt voor een vergelijkende analyse van diminutieven in Vlaanderen en Nederland. Dit lijkt waardevol onderzoeksmateriaal gezien het feit dat de verschillen tussen het origineel en zijn remake verder gaan dan alleen de verschillen in de uitspraak of het gebruik van regionaalgekleurde woorden. Aangezien het scenario telkens wordt aangepast om het voor het publiek zo natuurlijk mogelijk te maken (Goorix 2012: 58, Acke 2013: 36-37), kan worden aangenomen dat ze ook een waardevolle informatiebron zijn van subtielere taalverschillen, zoals bijvoorbeeld het kwalitatieve en kwantitatieve gebruik van verkleinwoorden.

\section{Betekenis van diminutieven: een struikelblok}

In semantisch opzicht houdt de diminutiefvorming in dat aan een woord de extra betekeniseenheid "klein" wordt toegevoegd. De betekenis van het grondwoord

${ }^{2}$ Het is weliswaar een corpus bestaande uit fictieve gesprekken maar vanwege de grote variatie van interpersoonlijke relaties en communicatieve situaties die erin gepresenteerd worden, kunnen we wel aannemen dat dit een goede weerspiegeling is van de communicatiestandaarden in Vlaanderen. Door drie critera toe te passen (taal: Nederlands, periode: 2000-2010, kijkcijfers: op basis van het rapport van het Vlaams Audiovisueel Fonds vzw uit 2010) kwamen we bij de volgende lijst uit: Loft (2008. In 2010 is de Nederlandse remake ervan verschenen), De zaak Alzheimer (2003), De helaasheid der dingen (2009), Frits \& Freddy (2010), Zot van A (2010. Het is de Vlaamse remake van Alles is liefde), Dossier K. (2009), Team Spirit 2 (2003), Team Spirit (2000), Ben X (2007), Pauline \& Paulette (2001). 
wordt zo gekleurd maar niet veranderd. De basisbetekenis van diminutieven heeft dus te maken met een klein formaat, maar hun betekenisspectrum is veel breder. In de vakliteratuur vindt men meerdere pogingen om hun betekenis te classificeren. Hun gemeenschappelijke draad wordt vooral gevormd door twee kwesties, namelijk de verwijzing naar een klein formaat en de emotionele lading die ze kunnen bevatten.

Zo'n verdeling in klein en emotioneel is al zichtbaar in de oudere werken over de diminutieven. Hüning (2013: 93) doet in zijn bijdrage "Iets over diminutieven. Nederlandse morfologie in de eerste helft van de 20 ste eeuw" 3 beroep op de opvattingen van onder andere Grimm en Te Winkel die al in de 19de eeuw beweerden dat de betekenis van de diminutieven op meer dan alleen het kleine formaat slaat. Heltberg (1964: 95-96) onderscheidde in de jaren zestig van de 20 ste eeuw in totaal drie types diminutieven. Ten eerste kunnen ze naar een klein formaat verwijzen, ten tweede kunnen ze ook emotioneel gekleurd zijn waardoor de instelling van de spreker tot uiting komt en ten derde kunnen ze tegelijk op een klein formaat duiden én de gevoelens van de spreker uitdrukken. Siatkowska (1967: 157) schrijft op haar beurt over twee types verkleinwoorden. Volgens haar bestaan er zogenoemde "echte" verkleinwoorden waarvan de betekenis inhoudt dat het object in kwestie klein is. Daarnaast bestaan er ook "emphatische" diminutieven. Hun gebruik wordt gemotiveerd door de emotionele lading van het moment waarop een taalhandeling geproduceerd wordt. Volgens Taylor (1995: 144-145) slaan de diminutieven op fysiek kleine dingen maar hij signaleert ook dat ze wel een aantal andere betekenissen kunnen hebben. Hij gaat ervan uit dat 'het kleine formaat' een kernbetekenis is en dat de andere betekenissen tot stand komen door een metafoor of metonymie toe te passen op de kernbetekenis. In het tweede geval kan het kleine formaat geassocieerd worden met het feit dat het gemakkelijker gevoelens kan opwekken en sneller aan minderwaarde, onbeduidendheid of kleinere hoeveelheid doet denken. Jurafsky (1996) ontwikkelt in zijn bijdrage "Universal Tendencies in the Semantics of the Diminutive" een cognitief model van het betekenisnetwerk van diminutieven met "kinderlijk" als prototypebetekenis waarvan andere (zowel semantische als pragmatische) betekenissen en functies afgeleid worden.

Dressler en Merlini Barabesi (2001) en Schneider (2013) wijzen er toch op dat het semantische uitgangspunt een struikelblok kan vormen voor de betekenisanalyse van de diminutieven. Dressler en Merlini Barabesi (2001: 45) benadrukken de beperkingen die de semantische analyse van de diminutieven met zich meebrengt. Het geeft namelijk geen beeld van hun pragmatische eigenschappen waardoor bepaalde functies van de diminutieven over het hoofd gezien worden. Zelf geven ze

${ }^{3}$ Hüning geeft in deze bijdrage een overzicht van de aanpak waarmee de Nederlandse diminutieven geanalyseerd worden. Hier observeert hij een verschuiving van de synchrone beschrijving van de vormen van diminutieven naar de analyse van hun functies in de standaardtaal. 
dus voorkeur aan de pragmatische analyse ${ }^{4}$. Schneider (2013: 144) laat aan de hand van voorbeelden uit het Engels zien dat hetzelfde verkleinwoord "een reeks van uiteenlopende en soms elkaar tegensprekende betekenissen kan uitdrukken." Daarom pleit hij voor de analyse van diminutieven met hun sociale functie in de gegeven context als uitgangspunt (Schneider 2013: 144-145). Zonder context ${ }^{5}$ zou het niet mogelijk zijn om de correcte betekenis van een diminutief af te lezen. Veidenberga (2013: 180) deelt die opvatting: volgens haar zijn diminutieven met bepaalde waarden verbonden die alleen zichtbaar zijn als de context ons bekend is.

\section{Taalspecificiteit}

Het gebruik van diminutieven, hoewel ze als een universele categorie worden beschouwd (cf. bv. Schneider 2003: 1) verschilt van taal tot taal zowel in kwantitatief als kwalitatief opzicht. Dat het gebruik van verkleinwoorden taalspecifiek is, betekent niet alleen dat ze in verschillende talen verschillende functies kunnen vervullen. Het is de moeite waard om te vermelden dat dit woorden zijn waar heel veel betekenis in zit. Niet alleen op het woordniveau maar ook op het niveau van de hele zin: iets is belangrijk of juist niet, er wordt vriendelijk met iets omgegaan of juist spottend, ironisch. Veidenberga (2013: 180) die een onderzoek deed naar de vertaling van diminutieven vanuit het Lets ${ }^{6}$ in het Engels, concludeert dat verkleinwoorden wel het enige teken kunnen zijn van hoe de spreker de objecten, personen of gebeurtenissen in kwestie ervaart. Deze informatie kan al dan niet helemaal verloren gaan bij het vertalen van de ene taal in de andere. Veidenberga (2013: 188) merkt op dat de emotionele lading van de Letse verkleinwoorden meestal verloren gaat terwijl het vrij goed lukt om de verwijzing naar een klein formaat te bewaren met behulp van andere lexicale middelen.

Hetzelfde verschijnsel observeren we ook in het Nederlands. Als we bijvoorbeeld aan de Nederlandse woorden feest en feestje denken, dan zien we een verschil tussen die twee. Een feest is professioneler, groter en anoniemer. Bij feestje denkt men daarentegen aan iets intiemers binnen bijvoorbeeld de familie- of vriendenkring. Als we feest en feestje vertalen in het Engels, dat over een veel beperktere mogelijkheid tot diminutiefvorming beschikt dan het Nederlands, dan krijgen we in beide gevallen party waaraan dit verschil niet meer af te lezen is. In het Pools, waar de mogelijkheid tot diminutiefvorming vrij groot is, krijgen we

${ }^{4}$ Hun onderzoek naar de verwerving van de diminutieven door kinderen bewees dat kinderen, als ze diminutieven gebruiken, niet naar de kleine maat van objecten verwijzen. De diminutieven worden dan eerder in hun attitudionele betekenis gebruikt.

${ }^{5}$ Zelf onderzoekt Schneider (2003) de betekenis van diminutieven in het Engels uitgaand van het soort taalhandeling waarin ze worden gebruikt.

${ }^{6}$ In het Lets vervullen de diminutieven in totaal 17 functies, onder andere prijzen, medelijden, spijt, vernedering en ondertoon. Voor de volledige opsomming zie Veidenberga (2013: 180). 
dan twee mogelijke vertalingen, namelijk przyjęcie en impreza waarbij przyjęcie formeler is dan impreza. Alleen van impreza kunnen we een verkleinwoord maken: imprezka. Dit doet echter in de eerste plaats denken aan een feest dat door jongeren gevierd wordt. De betekenis staat dus niet helemaal gelijk aan het Nederlandse feestje.

Wierzbicka $(1985,1992)$ heeft op haar beurt aandacht gevestigd op het feit dat diminutieven taalspecifiek zijn. Ze heeft gesuggereerd dat het diminutief ook een cultureel idee is in de interactie met anderen. Op basis van taalmateriaal uit het Pools en het Russisch heeft ze bewezen dat het frequente gebruik van diminutieven in deze talen een soort 'cultureel script' is voor gewenste warmhartigheid. In het Pools en in het Russisch is het namelijk gebruikelijk om diminuerende vormen van elkaars voornamen te gebruiken. Brown en Levinson (2011[1978]: 109) bewijzen aan de hand van het tot de Mayataalfamilie behorende Tzeltal dat het gebruik van diminutieven als uiting van genegenheid zich niet alleen beperkt tot aanspreekvormen. Het frequente gebruik van het partikel "ala" (klein) in een gesprek weerspiegelt een positieve instelling tegenover het onderwerp ervan. Ze stellen dat "het onderwerp van het gesprek niet zo belangrijk is als het feit dat er doorgegaan wordt met een gesprek dat rijkelijk geladen is met markers van emotionele overeenkomst" (Brown en Levinson 2011: 109). Travis (2004: 252) stelt dat het frequente gebruik van diminutieven een soort verwoording is van het culturele belang van bepaalde waarden.

Jurafsky (1996: 536-539) beschouwt op zijn beurt het concept 'diminutief' als een soort kern-satellietstructuur waarbij de basisbetekenis de kern is waar allerlei extra betekenissen omheen draaien. Dit 'betekenissennetwerk' is taalspecifiek en er kunnen zelfs verschillen optreden tussen meerdere variëteiten van dezelfde taal wat bevestigd wordt door het onderzoek van Travis (2004) naar het gebruik van diminutieven in het Colombiaanse Spaans en door het onderzoek van Terkourafi (1999) naar het gebruik van diminutieven in het Cypriotische Grieks. In het geval van Colombia zien we dat er achter de veel grotere distributie van het suffix -ito/ita ten opzichte van andere Spaanse diminutiefsuffixen een cultureel script staat om o.a. genegenheid te uiten tegenover gesprekspartners. In het tweede geval wordt beweerd dat terwijl het frequente gebruik van diminutieven in het Grieks over het algemeen met positieve beleefdheid te maken heeft, het $\mathrm{Cy}$ priotische Grieks minder mogelijkheden heeft om de diminutieven toe te passen in verschillende taalhandelingen. In tegenstelling tot het Grieks, wordt beleefdheid in het Cypriotische Grieks eerder uitgedrukt door andere taalelementen zoals meervoud en aanspreekvormen. Hier ziet Terkourafi (1999: 113) dat de nadruk op de sociale relaties ligt en niet op de gezelligheid zoals in het Grieks. De resultaten van die twee onderzoeken lijken bijzonder inspirerend als men aan het Nederlands denkt. Ten eerste omdat het Nederlands ook een pluricentrische taal is en ten tweede omdat er in Vlaanderen in tegenstelling tot Nederland twee diminutiefsuffixen naast elkaar fungeren in de informele dagelijkse communicatie. 


\section{Diminutief in het Nederlands: algemeen}

Het Nederlands behoort tot de talen die vrij vaak gebruik maken van diminutieven. Ze worden gevormd met behulp van het suffix $-j e^{7}$ en zijn vormvarianten (-tje, -pje, -kje en -etje). Het is opmerkelijk dat in het Nederlands niet alleen zelfstandige naamwoorden kunnen worden gediminueerd maar onder andere ook werkwoordsstammen (bv. praatje, zegje), adjectieven (bv. groentje, blauwtje) of bijwoorden (bv. stilletjes, zachtjes, eventjes). Even wordt ook gediminueerd als het als een modaal partikel wordt gebruikt (eventjes).

Hüning (2013: 90) wijst op een opvallend groter aantal diminutieven in het Nederlands ten opzichte van andere Germaanse talen, zoals bijvoorbeeld het Engels, hetgeen onderzoekers al in de 19de eeuw beschreven. Hier doet hij beroep op de opvattingen van Te Winkel die beweerde dat de diminutieven om deze reden zelfs als een apart type woorden geanalyseerd zouden moeten worden. Staverman (1953: 408) schrijft dat "[v]reemdelingen die onze taal nader leren kennen worden getroffen door de grote menigte verkleinwoorden die we gebruiken. En ze hebben gelijk. We vragen vrienden op een kopje thee en een glaasje wijn. We maken een fietstochtje van $70 \mathrm{~km}$ en een 14-daags reisje naar Zwitserland. Of we gaan met een retourtje een dagje naar Groningen [...]".

Waarom het diminutief in het Nederlands zo populair is, blijft ook een open vraag. De verklaring voor zo'n opvallend frequent gebruik van diminutieven in het Nederlands berust volgens Staverman (1953: 417) op de Nederlandse "kleinburgerlijke" mentaliteit. De verkleinwoorden zijn volgens hem "gezellig" wat het streven zou weerspiegelen naar "de rust en de welvaart" die voor de Nederlanders een ideaal waren. Het onderzoek van Kempe, Brooks en Gillis (2005) doelt weliswaar niet op de mogelijke verklaring waarom er zo veel verkleinwoorden in het Nederlands worden gebruikt maar het laat duidelijk zien waarom de diminutieven handig zijn vanuit een fonetisch standpunt. Kempe, Brooks en Gillis (2005: 148-149) bewijzen namelijk dat de diminutiefvormen beter passen in het toonritme van de zin. Door twee experimenten op een groep Engelse moedertaalsprekers (die het Nederlands niet machtig waren) uit te voeren, bewijzen ze dat de diminutieven een zekere regelmaat kunnen aanbrengen in het klemtoonpatroon. Bovendien zorgt het gebruik van diminutieven ook voor meer constantheid in de woorduitgangen, wat gunstig is voor woordsegmentatie. Er blijkt echter geen explicit onderzoek verricht te zijn naar hun frequentie in het moderne Nederlands in gesprekken die niet kind-geörienteerd ${ }^{8}$ zijn.

${ }^{7}$ Voor een overzicht van de discussie over het ontstaan van de diminutiefsuffixen zie bv. Bakema (1997: 207) en Hüning (2013: 91-93).

${ }^{8}$ Voor het onderzoek naar de verwerving van diminutieven door kinderen zie bv. Gillis 1997. Bakema (1997: 216) onderzoekt de frequentie van de diminutieven in een corpus van Middelnederlandse teksten. In Bakema, Defour en Geeraerts (1993: 133) treft men wel een aanwijzing dat 
Wat de mogelijke betekenissen van de diminutieven in het Nederlands betreft, onderneemt Staverman (1953: 409-412) een poging om de eerste uitgebreide classificatie ervan op te stellen. Zijn classificatie bevat vijf groepen: hij onderscheidt namelijk het werkelijke verkleinwoord (dat op een klein formaat duidt), het onderscheidende verkleinwoord (dat niet alleen op een klein formaat duidt maar tegelijk aangeeft dat het voorwerp in kwestie ook van een andere aard is, zoals bijvoorbeeld brood en broodje), het gezelligheidsverkleinwoord (dat met behaaglijkheid te maken heeft en verder nog subcategorieën kent, namelijk bijvoorbeeld keuken- en bescheidenheidsverkleinwoorden ${ }^{9}$ ), het geringer makende, bespottende en vernederende verkleinwoord (dat te maken heeft met het ontnemen van de waarde) en het kinderlijke verkleinwoord (dat betrekking heeft op iets kleins en beminnelijks). De laatste groep ziet Staverman (1953: 410-411) als de grootste en belangrijkste groep verkleinwoorden in het Nederlands. Hij beseft toch dat het frequente gebruik van de kinderlijke verkleinwoorden een gevaar met zich meebrengt. Het maakt namelijk niet uit dat het grondwoord al door een verkleinwoord werd vervangen, maar het verkleinwoord wordt nog een keer gediminueerd, bijvoorbeeld door er het adjectief "klein" voor te zetten. Dit vindt Staverman geen positieve ontwikkeling.

Bakema ${ }^{10}$, Defour en Geeraerts (1993) onderscheiden in hun bijdrage "De semantische structuur van het diminutief" twee dimensies van de basisbetekenis. Zij hebben het namelijk over diminuerende verkleinwoorden (die op een klein formaat in bredere betekenis slaan: ruimtelijk klein, kort, niet hevig of jong) en explicerende verkleinwoorden die in hun ogen tautologisch zijn omdat ze wel naar een klein formaat verwijzen maar in dit geval is de referent al klein dus eigenlijk kan er geen sprake zijn van verkleining. Bakema, Defour en Geeraerts (1993: 122) noemen dit "een onderscheid tussen letterlijke en figuurlijke betekenistoepassingen van het betekenismoment "klein"'. Verder wordt er aandacht besteed aan de evaluerende diminutieven die een positieve of negatieve waarde aan het object in kwestie toeschrijven. Bakema, Defour en Geeraerts (1993: 124) wijzen er daarbij op dat dit soort verkleinwoorden ook een approximerend of relativerend ${ }^{11}$ aspect kan hebben omdat

de diminutieven die een metasemantische functie hebben, "kwantitatief gezien de grootste groep vormen".

${ }^{9}$ Staverman (1953: 409) schrijft dat er zo veel verkleinwoorden gebruikt worden in de keuken omdat "[w]e zo aan deze verkleinwoorden zijn gewend, dat het moeite kost van bonen, erwten, wortels en saus te spreken." Bakema, Dafour en Geeraerts (1993: 122) schrijven dat het te danken zou zijn aan "de relatieve kleinheid van de referent". Het bestaansreden van de bescheidenheidsverkleinwoorden motiveert Staverman (1953: 409) met het feit dat "[e]en Nederlander altijd bang is voor overdrijving of opsnijderij; liever blijft hij te laag dan te hoog [...]."

10 Bakema (1997: 212) bewijst in zijn onderzoek naar het gebruik van de diminutieven in het Middelnederlands dat er toen al een gelijke set betekenissen zoals in het moderne Nederlands te observeren valt: "De verschillen tussen Middel- en Nieuwnederlands zijn niet zozeer kwalitatief, maar kwantitatief van aard".

${ }^{11}$ Het relativerende aspect is volgens Bakema, Defour en Geeraerts (1993: 125) duidelijk zichtbaar in diminutieven die eufemistisch worden gebruikt: "Tenslotte komt het relativerende be- 
"[d]oor een diminutiefformatie te gebruiken de spreker zich bescheiden opstelt en het gewicht van zijn verzoek of zijn handeling relativeert: door het verkleinwoord te gebruiken verkleint hij zichzelf'. Als de grootste groep verkleinwoorden zien Bakema, Defour en Geeraerts (1993: 133) de diminutieven die een metasemantische functie hebben. De metasemantische functies van diminutieven die intensivering, metafoor en metonymie omvatten, staan op hun beurt los van de denotationele en connotationele functies en zijn een aanwijzing dat een woord of een uitdrukking figuurlijk wordt gebruikt. Dit hoort volgens Bakema, Defour en Geeraerts (1993: 134) bij het pragmatische aspect van het gebruik van diminutieven.

\section{Diminutief in Vlaanderen}

\subsection{Twee suffixen}

Vandaag de dag worden er in de informele communicatie in Vlaanderen twee suffixen tegelijk gebruikt. De taalgebruikers vormen verkleinwoorden met het standaardsuffix -je en zijn vormvarianten, maar dit wordt vaak vervangen door het alternatieve suffix -ke dat niet tot het standaardtaalgebruik behoort en uitsluitend in het informele taalgebruik voorkomt. Pée (1936: 53) stelde in Dialectographie der Nederlandsche Diminutiva dat het gebruik van bepaald suffix afhankelijk kon zijn van de beschouwing: de voorkeur aan -ke zou worden gegeven in "de centra van katholieke overlevering" en de voorkeur aan -je in "de centra van protestantse overlevering". Taeldeman (2008: 33) wijst erop dat het suffix -ke oorspronkelijk alleen in Brabant, Limburg en Oost-Vlaanderen werd gebruikt en dat het ook in de andere provincies doorgedrongen is door de verspreiding van tussentaal als informele spreektaal. Vandekerckhove (2005: 391-392) schrijft dat het suffix -je goed geïntegreerd is in de spreektaal in Vlaanderen wat ze met een onderzoek aan de hand van Corpus Gesproken Nederlands bevestigt. Ze signaleert ook dat de distributie van beide suffixen en hun allomorfen in sommige dialecten bepaald wordt door de fonetische context wat ze tegelijk aan de hand van het Brabantse dialect illustreert. Daar is het gebruik van het suffix -je namelijk beperkt tot twee gevallen: woorden die op - $n$ eindigen voorafgegaan door een lange klinker, tweeklank of sjwa, bijvoorbeeld maantje geen maanke, en woorden die op - $t$ eindigen voorafgegaan door een lange klinker of medeklinker, bijvoorbeeld straatje en geen strateke.

tekenisaspect naar voren in eufemistische diminutieven als sproetje, puistje, plasje, snolletje en hoertje, waarbij de negatieve waarde van de referent die het basiswoord noemt, verzacht wordt door de diminutiefformatie. In dit opzicht staan eufemistische diminutieven haaks op depreciërende verkleinwoorden waar het diminutiefsuffix de negatieve waarde van het basiswoord versterkt. In beide gevallen gaat het om twee verschillende metaforische betekenistoepassingen van de centrale nuance "klein"”. 


\subsection{Functies in sociale interacties: resultaten van corpusonderzoek ${ }^{12}$}

De analyse van verschillende functies die de diminutieven kunnen vervullen in de corpusgesprekken, omvatte in totaal 497 verkleinwoorden die geschikt waren voor de analyse. Twee soorten diminutieven zijn buiten beschouwing gelaten, namelijk de diminutieven die deel uitmaken van vaste uitdrukkingen (bijvoorbeeld "volgens het boekje lopen') of, zoals Gillis (1997: 3-4) het noemt, "bevroren diminutieven", d.w.z. diminutieven die zonder suffix een andere betekenis hebben of diminutieven zoals bijvoorbeeld 'meisje' of 'beetje' die geen tegenhanger hebben zonder diminutiefsuffix. Van het totale aantal geanalyseerde diminutieven wordt 30\% (145) met het suffix -je gevormd. Hier moet meteen vermeld worden dat er geen enkele tendens tot het gebruik van -je in bepaalde functie zichtbaar is. Dit lijkt echter te liggen aan de fonetische beperkingen die voor het gebruik van -ke gelden ${ }^{13}$.

Tabel 1 geeft een overzicht van de functies die de diminutieven in de corpusgesprekken vervullen. Het is opvallend dat het gebruik van de verkleinwoorden in hun basisfunctie (klein formaat en kind-gerelateerd) vrij beperkt is. Ze zijn wat rijker vertegenwoordigd als een middel waarmee de personages hun gevoelens kunnen uiten. De grootste groep diminutieven zijn echter intensiverende diminutieven.

Tabel 1. De diminutieven in de corpusgesprekken in kwantitatief en kwalitatief opzicht (Wiercińska 2016)

\begin{tabular}{|l|c|c|}
\hline \multicolumn{1}{|c|}{ Functie } & Treffers & $\%$ \\
\hline kind-gerelateerd & 97 & $20 \%$ \\
niet kind-gerelateerd: & & \\
klein formaat & 33 & $7 \%$ \\
positief gevoel & 73 & $15 \%$ \\
negatief gevoel & 72 & $14 \%$ \\
intensiteit & 222 & $45 \%$ \\
\hline
\end{tabular}

12 Dit punt vat de resultaten samen van de analyse van de diminutieven die door Wiercińska (2016) verricht was met het oog op het beeld van de realiteit en de perceptie van de spreker die ze kunnen bevatten. Daarbij werd eigenlijk direct ook een set functies ontvangen die de diminutieven in de dagelijkse gesprekken kunnen vervullen.

${ }^{13}$ In het corpus werden de volgende paren geobserveerd kindje/kindeke, cadeautje/kadooke, jongetje/jongske, lievertje/lieveke, huisje/huiske, schatje/schatke (of schateke), eventjes/efkes, sleuteltje/sleutelke. Naar de aanleiding van de context van de situatie en soort taalhandeling waarin ze worden gebruikt, is er geen duidelijke motivatie zichtbaar voor de keuze van bepaald diminutiefsuffix. Daar komen nog meisje/meiske en beetje/beeteke bij. Meisje en beetje echter, in tegenstelling tot meiske en beeteke, lijken geen diminuerende functie te hebben. De verkleinwoorden die in het corpus uitsluitend met een standaardsuffix gevormd worden zijn bijvoorbeeld appartementje, zwartje, kleedje, feestje, vriendje, janetje, boeltje, nestje, complimentje, telefoontje, nachtje, kistje, keertje, kopietje, tuintje, eentje, handje, tandje, kusje, paardje, ventje, wijntje, zoontje, taartje, minuutje, gazetje, weekendje. 
Het komt er dus op neer dat de verkleinwoorden in de dagelijkse communicatie in Vlaanderen in totaal vijf verschillende functies hebben. De kind-gerelateerde diminutieven hebben betrekking niet alleen op kinderen zelf maar ook op verschillende objecten die in gesprekken met kinderen aan bod komen zoals in de volgende voorbeelden:

\section{(1) kind-gerelateerd}

Zot van A, 00:48:03\# BRUNO: Sluw ventje. Doodsbang dat hij z'n cadeautjes misloopt. $\rightarrow$ Bruno over zijn zoontje.

Team Spirit, 00:05:41\# ANNELIES: We krijgen binnenkort een spitske bij. Een priminiemke. Allez, ja als het een jongske wordt, natuurlijk $\rightarrow$ Annelies vertelt aan Erik dat zij en Stef een kindje krijgen.

Zot van A, 01:31:21\# JUF: Filmke zien? Welke wilt ge zien? $\rightarrow$ De juf wil samen met Boris, het zoontje van Bruno, een film kijken.

Diminutieven die impliceren dat voorwerpen die door de personages gebruikt worden, een klein formaat hebben, zijn het minst vertegenwoordigd in het corpus.

\section{(2) klein formaat}

Zot van A, 00:11:32\#

Pauline \& Paulette, 00:58:41\#

Frits \& Freddy, 00:05:49\#
LYDIA: Ik hoop dat ze fruit gaat halen. Mandarijntjes. Met van die takskes erop. $\rightarrow$ Lydia over de mandarijntjes voor de intocht van Sinterklaas.

PAULETTE: Tof livingske, goed ingericht keukentje. $\rightarrow$ Paulette over haar nieuwe appartement dat veel kleiner zou zijn dan haar oude huis.

FREDDY: Zo'n beer van een vent die naast zo'n vlooienbaal staat te wachten tot ie $z$ 'n kakske en $z$ 'n pieske heeft gedaan. $\rightarrow$ Freddy over de behoeftes van een kleine hond waarvan zijn buren de bazen zijn

Verkleinwoorden waarmee de spreker zijn houding en/of emotionele staat kan uitdrukken, worden zowel positief als negatief bedoeld. Ze hebben betrekking op de personen en al dan niet materiële objecten uit de naaste omgeving van de personages:

\section{(3) positief gevoel}

Team Spirit, 00:43:54\# VIK: Jos, eigenlijk zijt ge de ene van onze bende die geslaagd is in zijn leven. Eigen zak, goed vrouwke, kindjes. $\rightarrow$ Vik mist de stabiliteit die Jos wel heeft.

Zot van A, 01:18:22\# LYDIA: Arno, vindt ge mij nog aantrekkelijk? ARNO: Tuurlijk, zotteke. $\rightarrow$ Arno spreekt zijn vrouw liefkozend aan. 
Loft, 00:15:09\#

FILIP: Sorry dat $m$ ' $n$ vriendinke in de champagne gevlogen is. Ik zou je voorstellen. Dat is een collega van op de bureau. En dat is een collega van onder de bureau. Oei, oei, mijn broer komt me al op mijn dak geven. Dag, Chris. Alles goed? $\rightarrow$ Filip lachend over een collega die net iets te veel heeft gedronken.

(4) negatief gevoel

Team Spirit, 00:17:15\#

De zaak Alzheimer, 00:19:10\#

Loft, 00:45:57\#
VADER VAN VIK: Zijt ge nu loopjongske geworden voor die loosers van die vriendjes van $u$. $\rightarrow$ Vader van Vik reageert ironisch als zijn zoon vraagt of een van zijn vrienden in zijn vaders bedrijf soms niet aangesteld zou kunnen worden.

FREDDY: Dat slotroest, zeker bij de goedkope modellekes. $\rightarrow$ Freddy over de BMW's waar hij een hekel aan heeft.

MARNIX: Ah ja, wat staat er in al die vrouwenboekskes? Twee dingen, Anja. Wat een varkens de venten zijn en hoe dat ge ze moet verleiden. $\rightarrow$ Marnix ironisch over de tijdschriften voor vrouwen.

Het is opvallend dat de meerderheid van de gevonden diminutieven met intensiteit te maken heeft die dan nog in drie richtingen lijkt te lopen. Ten eerste kan het gebruik van een diminutief de ernst van de situatie verzachten of de al dan niet materiële waarde van de zaken/voorwerpen waar de spreker het over heeft, kleiner of minder belangrijk doen lijken wat de volgende uitspraken goed kunnen illustreren:

(5a) intensiteit $\rightarrow$ verzachting van de ernst van de situatie, materiële waarde of belang

Team Spirit 2, 00:37:37\# JOS: Ik ben gewoon van een trapke gevallen $\rightarrow$ Hij ligt nu in het ziekenhuis en er is een ernstig probleem met zijn wervelkolom omdat hij geen gevoel heeft in zijn benen.

De helaasheid der dingen, GUNTHER: Meneer, hier Gunther Strobbe he. Mijn vader kan van00:46:20\#

Loft, 00:25:20\# daag niet komen werken. Hij is een beeteke ziek. $\rightarrow$ Celle is ernstig ziek vanwege overmatig gebruik van alcohol.

VINCENT: De loft is af. Tis een kadooke van mij voor jullie allemaal. $\rightarrow$ Hij stelt een luxe loft ter beschikking van zijn vrienden.

In de eerste twee situaties geven de diminutieven een indruk dat de situatie eigenlijk niet zo ernstig is als het lijkt. De uitspraak van Jos die een ongeluk had tijdens de voetbaltraining, klinkt zelfs heel onschuldig terwijl hij geen gevoel meer in zijn benen heeft en zijn blaas niet meer kan controleren. Hetzelfde geldt voor Gunther. "Een beeteke ziek" doet denken aan je even niet lekker voelen maar Celle maakt het niet goed en de kijker krijgt de indruk dat hij medische hulp nodig heeft. De loft en dus het "kadooke" van Vincent is op zijn beurt geen cadeau dat zomaar geregeld en gegeven kan worden.

Verder is de intensiverende rol van diminutieven duidelijk zichtbaar in drie soorten taalhandelingen, namelijk verzoeken, voorstellen en weigeringen. Afhankelijk 
van de taalhandeling, kunnen diminutieven de perceptie van de uitspraken bij de gesprekspartners sturen: verzoeken en voorstellen klinken minder dwingend en weigeringen klinken minder bot of hard wat aan de hand van de volgende voorbeelden geïllustreerd kan worden:

(5b) intensiteit $\rightarrow$ verzachting van verzoek, voorstel en weigering

Loft, 01:01:00\#

Frits \& Freddy, 00:19:24\#

De zaak Alzheimer, 01:39:15\#

De helaasheid der dingen, 01:00:01\#

Zot van A, 00:02:29\#

Loft, 00:24:40\#
MARNIX: Vince, kunt gij efkes naar haar gaan klappen? Kunt gij niet zeggen... dat ik haar graag zie en dat die Anja liegt? U zal ze geloven, Vince. $\rightarrow$ Marnix heeft hulp van Vincent nodig omdat zijn vrouw hem niet meer wil zien nadat hij vreemd is gegaan.

FREDDY: Ik heb hem maar efkes nodig. Half uurke, max. $\rightarrow$ Freddy wil de auto van zijn buren lenen.

LEDDA: Vincke... Zou ge mij een plezier willen doen? Als ge nog eens komt, breng me dan een pakske Stimorol mee. $\rightarrow$ Ledda vraagt dat Vincke een pakje kauwgom meeneemt als hij nog op bezoek komt.

BREEJEN: Een kaffeke? Kleine ga 's... $\rightarrow$ Breejen nodigt Nele van de jeugdzorg uit om een kopje koffie te drinken met de Strobbes.

TOM: Anna, meiske, zo werkt 't niet. Ik kan toch geen uitzonderingen beginnen te maken, zelfs niet voor mijnen kleinzoon. $\rightarrow$ Tom weigert om extra aandacht te schenken aan zijn kleinzoon tijdens de intocht van Sinterklaas.

FILIP: Nee schat, ik blijf hier efkes bij de vrienden. $\rightarrow$ Filip is zijn eigen trouwfeest beu en heeft geen zin om naar de cadeautjes te gaan kijken met zijn vrouw.

Het verzoek van Marnix om "efkes met Miriam gaan klappen" zou even veel moeite van Vincent vragen als "met Miriam gaan klappen". Hetzelfde geldt voor een "pakske Stimorol": het is even grote moeite om "een pak Stimorol" te brengen. "Half uurke" van Freddy zou niet korter zijn dan "half uur". Juist dankzij diminutieven lijkt het er echter op dat er minder wordt gevraagd en dat het minder inzet zou eisen om aan het verzoek te voldoen. Hetzelfde kunnen we observeren in voorstellen. Het diminutief suggereert dat de uitvoering van het verzoek niet veel engagement eist. Een "kaffeke" maken is toch even simpel als een "koffie" maken. Filip op zijn beurt, als hij zegt dat hij "efkes" bij zijn vrienden blijft, geeft zijn vrouw een indruk dat hij binnen een niet al te lange tijd wel aan haar verzoek voldoet terwijl hij dat helemaal niet van plan is. De weigering van Tom klinkt minder onbeschoft dankzij extra aanspreking "meiske".

Dit laatste voorbeeld geeft een aanwijzing voor het derde aspect van de intensiverende rol van de diminutieven in de sociale interacties. Het gaat om diminutieven die in negatieve uitspraken worden gebruikt. Het is echter niet hun bedoeling om negatieve gevoelens te uiten tegenover de gesprekspartner of objecten/zaken waar de gesprekspartners het over hebben maar juist om de negatieve lading van 
de hele uitspraak te verzachten. Dat is het best zichtbaar in de uitspraken die gebruik maken van aanspreking in de vorm van een diminutief:

(5c) intensiteit $\rightarrow$ verzachting van de negatieve lading van de hele uitspraak

Loft, 00:32:12\# CHRIS: Schatke, kunt ge toch een beetje enthousiasme tonen? $\rightarrow$ Chris vindt het vervelend dat zijn vrouw duidelijk laat zien dat zij van zijn feestje niet geniet. Hij spreekt haar daarop aan

Loft, 00:46:22\# ANJA: Vijf minuten? Sarah, schateke, ik sta hier potverdikke al 'n uur op u te wachten. Tis geluk dat ik hier gesponsord word. $\rightarrow$ Anja maakt een opmerking dat ze heel lang op haar collega moest wachten.

In kwantitatief opzicht waren de intensiverende diminutieven het meest frequent in de uitspraken waarin ze betrekking hadden op de materiële waarde van de objecten in kwestie of de ernst van de situatie.

\section{Gemeenschappelijk 'setje' betekenissen? Vergelijkende analyse van Loft/Loft en Zot van A/Alles is liefde}

Er rijst de vraag of het setje functies die de diminutieven in het corpus vervullen, specifiek alleen voor Vlaanderen zou zijn of dat het gezien zou kunnen worden als een cultureel script in heel het taalgebied. Aangezien twee films uit het corpus hun 'Hollandse' versies hebben (de Vlaamse Loft kreeg in 2010 de remake onder dezelfde titel en Zot van $A$ is de remake van Alles is liefde) werd er een poging ondernomen om het gebruik van de diminutieven in de Vlaamse en Hollandse versie met elkaar te vergelijken.

Bij de kwantitatieve analyse valt snel op dat er veel meer verkleinwoorden gebruikt worden in de Vlaamse versies. In de Hollandse Loft zijn er in totaal 61 verkleinwoorden gevonden die voor het onderzoek relevant waren terwijl er in zijn Vlaamse tegenhanger er 91 zijn. Dat is één derde meer. Alles is liefde bevatte op zijn beurt 55 verkleinwoorden terwijl Zot van $A 96$ voor analyse vatbare diminutieven leverde. Dat is bijna twee keer zo veel. Tabel 2 geeft hier een overzicht van samen met het aantal treffers.

Tabel 2. Kwalitatieve en kwantitatieve gebruik van diminutieven in Loft, Loft, Alles is liefde en Zot van A

\begin{tabular}{|l|c|c|c|c|c|c|}
\hline & $\begin{array}{c}\text { kind- } \\
\text { gerelateerd }\end{array}$ & $\begin{array}{c}\text { klein } \\
\text { formaat }\end{array}$ & $\begin{array}{c}\text { positief } \\
\text { gevoel }\end{array}$ & $\begin{array}{c}\text { negatief } \\
\text { gevoel }\end{array}$ & intensiteit & totaal \\
\hline Loft (NL) & 1 & 3 & 20 & 17 & 18 & 59 \\
\hline Loft (VL) & 1 & 0 & 18 & 17 & 55 & 91 \\
\hline $\begin{array}{l}\text { Alles is } \\
\text { liefde }\end{array}$ & 11 & 5 & 10 & 7 & 22 & 55 \\
\hline Zot van A & 20 & 7 & 16 & 11 & 42 & 96 \\
\hline
\end{tabular}


In beide gevallen zijn de diminutieven in hun basisfunctie (1) even schaars vertegenwoordigd. Het aantal diminutieven die positieve of negatieve gevoelens uitdrukken is in beide versies ook niet flink uiteenlopend. Bij nader inzien kan geconstateerd worden dat de diminutieven in de Hollandse films precies dezelfde functies vervullen: ze kunnen onder andere de al dan niet materiële waarde van het object in kwestie kleiner doen lijken (2), positieve of negatieve gevoelens van de spreker uitdrukken $(3,4)$ of de indruk geven dat het verzoek minder inzet vraagt van de gevraagde persoon (5) wat de volgende voorbeelden illustreren.

(1) De juf met wie de vader van Boris een affaire had, komt even bij hen op bezoek en stelt voor dat ze met Boris een film gaat kijken.

Zot van $A, 01: 31: 21 \#$

JUF: Filmke zien? Welke wilt ge zien?

Alles is liefde, 01:29:43\#

JUF: Hé, een filmpje kijken. Dat is net waar ik zin in had.

(2) In het gebouw dat door Vincent/Matthias ontworpen is, zijn er dure appartementen te koop. Chris/Bart kan het niet betalen. In beide versies vermindert het diminutief de materiële waarde van het appartement.

$\operatorname{Loft}(V L), 00: 11: 55 \#$

BARBARA: Seg, moete gij hier geen appartementje kopen?

Loft (NL), 00:10:14\#

NATHALIE: Niets voor jullie? Appartementje aan het water?

(3) Chris/Bart lachend over de meisjes met wie zijn broer van het feestje geniet.

Loft (VL), 00:15:28\#

CHRIS: Ja. Vriendinnekes van Vicky? Of zijt ge aan het babysitten?

Loft (NL), 00:13:44\#

BART: Vriendinnetjes van Kimmy? Of ben je aan het babysitten?

(4) Ann ironisch over de loft die Chris/Bart met zijn vrienden deelt.

Loft (VL), 00:57:04\#

ANN: Hoeveel vrouwen hebt ge al eigenlijk meegenomen naar die loft van $u$ ? Die loft die ge deelt met uw vriendjes. Hou uw gezeik voor de volgende die ge daar mee naartoe neemt.

Loft (NL), 00:54:50\#

ANN: Hoeveel vrouwen heb je eigenlijk meegenomen naar die loft van je? Die loft van jou en je vriendjes?

(5) Anna/Klaasje vraagt aan haar vader om extra aandacht te geven aan haar zoon tijdens de intocht van Sinterklaas.

Zot van A, 00:02:22\#

ANNA: Ik vraag toch niet te veel. Gewoon wat mandarijnekes, wat speculaas, een aai over z'n bolleke. Ik

Alles is liefde, 00:03:15\#

zal ervoor zorgen op de eerste rij staan, ja?

KLAASJE: Gewoon handje pepernoten, aai over zijn bol, klaar.

Het grootste verschil in het gebruik van diminutieven in de Vlaamse en Hollandse versies zit in het gebruik van diminutieven die te maken hebben met intensiteit dus ten eerste diminutieven die in verzoeken en weigeringen gebruikt worden om ze minder dwingend en bot te laten klinken en ten tweede diminutieven 
die de ernst van de situatie of materiële waarde van objecten kleiner doen lijken. Dit verschil blijkt vooral te ontstaan door het frequente gebruik van het modale partikel even dat meestal gediminueerd wordt in de Vlaamse films. In de Hollandse versies komt even weliswaar regelmatig voor, maar eventjes in totaal maar twee keer in beide films. Het verschil tussen "even" en "efkes" is in de meeste voorbeelden heel erg subtiel. Afhankelijk van de context van de gegeven situatie geeft "efkes" bijvoorbeeld een indruk dat de omstandigheden niet zo serieus genomen moeten worden $(6,7)$, dat er minder tijd voor uitgetrokken moet worden $(8)$ of dat er minder inzet gedaan moet worden (9).

(6) Vincent/Matthias vraagt aan zijn vrienden dat ze de politie niet op de hoogte brengen dat ze een vrouwenlichaam in hun loft hebben gevonden.

Loft (VL), 00:09:55\#

Loft (NL), 00:08:11\#
VINCENT: Wacht 's efkes, Chris. Ge weet toch wat er dan gebeurt als we politie bellen. Wilt ge dat Ellen alles te weten komt?

MATTHIAS: Ho ho ho, wacht even! Je weet wat er gebeurt als we dat doen. Wat wil je nou? Wil je dat Eva alles te weten komt?

(7) De vrouw van Luc/Rob lijdt aan suikerziekte en moet tijdens het feestje haar suiker gaan meten. Loft (VL), 00:12:53\# LUC: Ze voelde zich wat draaierig. Ze is efkes haar suiker gaan meten.

Loft (NL), 00: 11:03\#

ROB: Ze voelde zich een beetje draaierig. Ze is haar suiker gaan meten.

(8) Nadat Kees/Fred op het allerlaatste moment heeft geweigerd om te trouwen, praat hij met de zus van zijn partner.

Zot van $A, 01: 16: 11 \#$

ASTRID: Die is efkes gaan liggen.

Alles is liefde, 01:15:12\#

FRED: Ik heb gewoon efkes tijd nodig. Een paar dagen.

KIKI: Nee, die is even gaan liggen.

KEES: Ik heb gewoon even tijd nodig. Een paar dagen rust, een beetje lucht in m'n kop.

(9) Astrid/Kiki wil geen date met Paul/Valentijn. Ze vindt dat hij helemaal geen grote moeite moest doen om haar te zien.

Zot van A, 00:41:11\#

ASTRID: Efkes aan de chauffeur gevraagd of hij tot hier kon rijden. Knap, zeg. Dit is gewoon geen goed idee. Ik bedoel, gij hebt drie huizen, gij hebt 300 vriendinnekes, minstens. [...] Dat is toch zo? Ge moet efkes met uw kniepees zwengelen, en iedereen valt al flauw

Alles is liefde, 00:36:40\# KIKI: Wat heb je gedaan dan? Heb je je helemaal hierheen laten rijden? [...] Je hebt nooit je best hoeven doen. Je hoeft maar met je bakkebaarden te wapperen en iedereen valt flauw.

Het valt op dat sommige uitspraken van bepaalde personages in de Vlaamse versies veel directer zijn. Dit gebeurt vooral als ze iets negatiefs willen zeggen. In zulke gevallen $(10,11)$ zorgt "efkes" voor de verzachting van de negatieve toon. 
(10) Filip/Tom is zijn eigen trouwfeest beu.

Loft (VL), 00:24:45\#

Loft (NL), 00:21:02\#
FILIP: Efkes genoeg kakvolk gezien.

TOM: Ik heb het even helemaal gehad met die types.

(11) Annette/Alicia die verantwoordelijk is voor de intocht van Sinterklaas is boos op haar stagiair die er niet voor kan zorgen dat Zwarte Pieten op tijd aankomen.

Zot van A, 00:08:00\#

Alles is liefde, 00:06:15\#
ANNETTE: Sorry, maar ik heb nu efkes geen tijd voor uw puberale seksuele fantasieën.

ALICIA: Ik weet niet hoe serieus jij dit allemaal neemt maar dankzij jou lopen wij een half uur achter op schema.

Het volgende verschil zit in het gebruik van diminutieven die tevens een aanspreking zijn. Daarmee uiten de personages ten eerste hun positieve gevoelens en ten tweede kunnen ze ook de negatieve lading van hun uitspraak verzachten. In de Hollandse versies zijn er over het algemeen minder aansprekingen dan in de Vlaamse versies maar de aansprekingen die een diminutiefvorm hebben, behoren eigenlijk tot de uitzonderingen (in totaal vier in beide films). Daardoor lijken de uitspraken van de Hollandse personages, vooral waar de aanspreking helemaal niet voorkomt, doeltreffender en dwingender, zoals bijvoorbeeld in de volgende situaties.

(12) Arno/Ted kan met zijn gezin niet mee naar de intocht van Sinterklaas omdat hij moet werken.

Zot van A, 00:01:12\#

Alles is liefde, 00:02:50\#
ARNO: Nee, lieveke dat kan niet. Papa moet werken vandaag.

TED: Nee, schat, papa moet werken

(13) Tom die Sinterklaas gaat vertolken tijdens de intocht, wil geen extra aandacht geven aan zijn kleinzoon.

Zot van A, 00:02:08\#

TOM: Anna, meiske. Ik sta juist op het punt om buiten te stappen. [...] Anna, meiske, zo werkt ' $t$ niet. Ik kan geen uitzonderingen beginnen te maken, zelfs niet voor mijnen kleinzoon. [...] Luister, schatke, dat is echt mijn probleem niet, hoor. Ik heb ervoor niet gekozen om uw huwelijk op te blazen.

Alles is liefde, 00:03:09\#

Klaas, ik sta net op het punt om de deur uit te gaan. [...] Ik kan geen uitzonderingen maken, ook niet voor mijn kleinzoon. [...] Jullie zijn zo flink geweest om jullie huwelijk uit elkaar te laten klappen dan moet je ook zo flink zijn om de consequenties te aanvaarden.

(14) Alain/Victor brengt zijn vriend op de hoogte dat zijn moeder op hun trouwfeest wil zingen wat uiteraard slecht nieuws is.

Zot van $A, 00: 45: 58 \#$

Alles is liefde, 00:43:12\#
ALAIN: Zeg, schateke. Ik denk dat onze moeder toch wil doorzetten.

VICTOR: Luister, ik ben bang dat m'n moeder het toch wil doen. 
(15) De baas van Fred/Kees informeert hem dat hij wat eerder naar huis gaat omdat het pakjesavond is.

Zot van A, 01:29:42\#

Alles is liefde, 01:28:33\#
BAAS: Fredje, ik ben vandaag wat eerder weg.

BAAS: Ik ben vandaag wat eerder weg.

Het gesprek van Arno en zijn dochtertje (12) klinkt dankzij "lieveke" wat warmer dan alleen met "schat". De weigering van Tom (13) in Zot van A lijkt dankzij diminuerende aansprekingen minder bot dan de weigering in Alles is liefde. De mededeling van Alain (14) klinkt op zijn beurt voorzichtiger omdat het erop lijkt dat het de impact van slecht nieuws moet verzachten. De mededeling van de baas van Fred (15) klinkt dankzij het diminutief openhartiger. In Alles is liefde lijkt het meer op een droge mededeling.

Het gebruik van diminutieven als aanspreekvormen en vooral gediminueerde voornamen doet denken aan de eerder besproken opvattingen van Wierzbicka $(1985,1992)$ die het frequente gebruik van diminutieven en vooral gediminueerde vormen van voornamen ziet als cultureel gewenste warmhartigheid. Dit is duidelijk zichtbaar in de Vlaamse films maar ontbreekt meestal in hun Hollandse tegenhangers.

\section{Besluit}

Uit de analyse van 497 verkleinwoorden in het corpus blijkt dat ze in de dagelijkse sociale interacties drie functies vervullen. Ze worden ten eerste gebruikt in hun basisbetekenis (duidend op een kind of een klein formaat), ten tweede hebben ze een emotionele waarde (positief of negatief) waardoor de perceptie en de instelling van de spreker bekend worden gemaakt. Het is opvallend dat de verkleinwoorden in hun basisbetekenis eigenlijk een heel kleine groep vormen: slechts 97 treffers waren kind-gerelateerd en nog minder, 33 treffers hadden betrekking op een klein formaat. Diminutieven werden frequenter gebruikt als uitdrukking van de gevoelens van de spreker ( 73 treffers als uiting van positief gevoel en 72 treffers als uiting van negatief gevoel). Bijna de helft van de treffers (222) vervulde een intensiverende functie. Ze hadden namelijk te maken met een tendens tot verzachting die verder nog drie aspecten had. Ten eerste werden zulke verkleinwoorden gebruikt om de al dan niet materiële waarde van de objecten waar de personages het net over hadden of de werkelijke ernst van de situatie te camoufleren. Ten tweede kwamen ze goed van pas in drie soorten taalhandelingen, namelijk verzoeken, voorstellen en weigeringen. Daar wekken ze de indruk dat er minder inzet vereist is om aan een verzoek of voostel te voldoen. De weigeringen op hun beurt klonken milder en minder direct. Ze konden ook de negatieve lading van de hele uitspraak verzachten (dit was het beste zichtbaar bij de verkleinwoorden die tevens aansprekingen waren). 
Op basis van de vergelijkende analyse van het gebruik van diminutieven in Loft, Zot van A en hun Hollandse tegenhangers kan geconcludeerd worden dat ze in beide variëteiten van het Nederlands gelijke functies hebben. Het doornemen van het aantal diminutieven in elke film laat echter zien dat de diminutieven vaker in Vlaamse films gebruikt worden. In kwalitatief opzicht zijn er twee subtiele verschillen zichtbaar. In de Hollandse films wordt er minder naar gestreefd om de lading van de uitspraak te verzachten. Diminutieven worden er ook bijna helemaal niet als aanspreekvorm gebruikt waardoor de uitspraken genegenheid of een zachter karakter missen.

\section{Bibliografie}

Acke, Stefan (2013): "Een onoverbrugbaar verschil? Een literatuurstudie en vergelijkende filmanalyse van het Nederlandse Alles is Liefde en zijn Vlaamse remake Zot van A". Ongepubliceerde MA-thesis. Universiteit Gent.

Bakema, Peter (1997): "Het onvoltooid verleden verkleinwoord". In: Tijdschrift voor Nederlandse taal- en letterkunde. Jaargang 113, 201-211.

Bakema, Peter, Patricia Dafour en Dirk Geeraerts (1993): "De semantische structuur van het diminutief'. In: Forum der Letteren, Jaargang 1993, 121-137.

Brown, Penelope, Stephen C. Levinson (2011[1978]): Politeness: Some Universals in Language Usage. Cambridge: Cambridge University Press.

Caluwe, Johan de (2006): “Tussentaal als natuurlijke omgangstaal in Vlaanderen”. In: Johan De Caluwe, Magda Devos (eds.), Structuren in talige variatie in Vlaanderen. Studia Germanica Gandensia. Jaarboek 2006. Gent: Academia Press, 19-35.

Dressler, Wolfgang, Lavinia Merlini Barbaresi (2001): "Morphopragmatics of Diminutives and Augmentatives: On the Priority of Pragmatics over Semantics". In: Istvan Kenesei, Robert M. Harnish (eds.), Perspectives on Semantics, Pragmatics, and Discourse: A Festschrift for Ferenc Kiefer. Amsterdam: John Benjamins, 43-58.

Gillis, Steven (1997): “The Acquisition of Diminutives in Dutch", laatst geraadpleegd op 18.12.2015. $<$ http://www.cnts.ua.ac.be/papers/1997/DIM_Draft.pdf $>$.

Goorix, Sarah (2012): "Wederzijdse remakes: een literatuurstudie en een comparatieve filmanalyse van de Vlaamse film Loft en zijn Nederlandse remake". Ongepubliceerde MA-thesis. Universiteit Gent.

Heltberg, Kristine (1964): “O deminutywach i augmentatywach". In: Prace Filologiczne 18(2), 93-102

Hüning, Matthias (2013): "Iets over diminutieven. Nederlandse morfologie in de eerste helft van de 20ste eeuw". In: Theo Janssen, Ton van Strien (eds.), Neerlandistiek in beeld. Amsterdam: Stichting Neerlandistiek VU \& Münster: Nodus Publikationen, 89-98.

Jurafsky, Daniel (1996): "Universal Tendencies in the Semantics of the Diminutive". In: Language 72, 533-578.

Kempe, Vera, Patricia J. Brooks en Steven Gillis (2005): "Diminutives in Child-directed Speech Supplement Metric with Distributional Word Segmentation Cues". In: Psychonomic Bulletin \& Review 12(1), 145-151.

Pée, Willem (1936): Dialectologie der Nederlandsche Diminutiva, 2dln. Gent: Koninklijke Vlaamse Academie voor Taal- en Letterkunde.

Schneider, Klaus P. (2003): Diminutives in English. Tübingen: Max Niemeyer Verlag.

Neerlandica Wratislaviensia 26, 2016

(C) for this edition by CNS 